\section{研:究:発:表:講:要: 旨}

昭和 40 年 7 月 1 日（木） $9: 30 \sim 17: 00$

於 東京都千代田区神田駿河台 1 日本化学会講堂

\section{1. 長野県信陽鉱山の蝛石鉱床について}

藤井紀之

1)目的信陽鉣山は県下最大の蟬石鉱山で，蝋 石乙農薬用クレーを合せて月産約 $2000 \mathrm{t}$ の出鉱がある. この研究は鉱床の産状からその地質的生成機構を明らか にし，あわせて鈗石の性質との関連を把握する目的で行 なわれた。

2）経 過信陽鉱山の採掘は露天階段掘でなされ ており，切羽の大きさは幅約 $200 \mathrm{~m}$ ，奥行約 $150 \mathrm{~m}$ ，高 さ約 $100 \mathrm{~m}$ に及ぶ大規模なものである。この切羽につい て1/500の縮尺で，鉱石と原岩の種類を区分した詳細な 鉱床図を作製し，地質と蝋石化作用との関係について検 討した。また各種の鉱石約 30 個についてX線回折，顕 微鏡観察, 化学分析, 耐火度試験を行ない, それぞれの 鉱石の性質について比較検討した。

3）結 論信陽鉱山附近の地質は中新世の緑色凝 扊岩類と，乙れを貫人する閃緑玢岩よりなる。緑色凝灰 岩類は粗粒煇緑岩質熔岩, 石質凝兏岩, 凝死岩, 凝灰質 砂岩，黑色頁岩などからなり，一般に下部は輝緑岩熔岩 に富み上部では頁岩，凝死岩などが優勢である。閃緑玢 岩は径 $5 \mathrm{~m}$ 前後の石英の捕獲結晶を含むのが特街で, 不 規則な形状の岩脈に岐れて緑色凝死岩中に貫入ないし選 入している. 変質作用は蝋石化作用と珪化作用に大別さ れ，局部的には絹雲母化作用，黄鉄鉱の鉱染が認められ る。もっとも特徵的なのは母岩によって変質作用がかな り明瞭に規制されていることで，おおよそ次のような傾 向が認められる。

○珪化作用を受け易いもの

輝緑岩, 頁岩

○螎石化作用を受け易いもの

砂岩, 凝灰岩

○中間的なもの

石質凝灰岩，玢岩

なお，絹雲母化作用は断層に沿って認められることが 多く，黄鉄鉱の鉱染には必ずしも規則性は認め難い。乙 れらの中で石質凝扊岩は層理に沿った部分が蝉石化し， 中心部は珪化を受けている場合が多い、また比較的多孔 質な母岩が多く蝻石化され，媻硬・緻密な母岩では珪化 作用が優勢である。乙のような事実は変質作用が比較的 弱酸性の Al に富古溶液によって行なわれたてとを示し ている。恐らく玢岩貫入後の熱水作用によるものと推定 される.従って鉿石の組織・組成鉱物にも母岩による相 違が明瞭に認好られる。しかし，两的火度はSK28～30で
活とんど一定している。利用面との関係については，な お今後の研究に末ちたい。

(工技院地質調査所鉳床部)

2.マグネシアの焼結に対するシリカ添加の影響（そ の 2)

○浜野健也・富樫広光

1) 目的今年1月の䈍基基礎討論会で, $\mathrm{MgO} の$ 焼結に対する $\mathrm{SiO}_{2}$ 添加の影響を等温収縮測定の結果か ら検討し， $1200^{\circ} \mathrm{C}$ 以下の温度範囲では，一般に $\mathrm{SiO}_{2}$ の 添加は $\mathrm{MgO} の$ 焼結を阻害するが, $0.3 \%$ の微量添加の 場合にのみ促進效果が認められること，乙の原因の一つ は搪散焼結に対する見掛上の活性化エネルギーの低下て あるととなどを報告した。今回はさらに高温度範囲まで 検討し, $\mathrm{SiO}_{2}$ の添加が $\mathrm{MgO}$ の焼結に如何なる影響を 与えるか，特に0.3\% の微量の添加が，実際の素地焼結 の場合に促進効果を与光るか否かという問題を主とし， さらに概括的に見て $\mathrm{SiO}_{2}$ の添加が， $\mathrm{MgO}$ の観結に如 何高る影響を与えるかという点を併せ検討した。

2) 実験・結果関東化学製の鹿印特級 $\mathrm{Mg}(\mathrm{OH})_{2}$ に，2〜 $5 \mu$ 範网の光学ガラス用珪石微粉末を $0 \sim 8 \mathrm{wt} \%$ 配合し，小円板状試験片にプレス成形し，最高 $1900^{\circ} \mathrm{C}$ までの各温度に 4 時間燒成したものについて種々の測定 を行なった。まず陚験片の焼成収縮率を測定し， $\mathrm{MgO}$ $\mathrm{SiO}_{2}$ 系試験片の焼結は温度の上昇とともに進むが， $1000^{\circ} \mathrm{C}$ 以上の温度で一時的に停滞する。乙の停滞温度 範囲は $\mathrm{SiO}_{2}$ 添加量の多くなるほど狭くなる。900〜 $1000^{\circ} \mathrm{C}$ 以下の低温度範囲では一般に $\mathrm{SiO}_{2}$ の添加は $\mathrm{MgO}$ 素地の焼結を阻害するが，0.3〜0.7\%の微量添加 の場合にのみ促進効果が望められるが， $1200^{\circ} \mathrm{C}$ 以上に なるとすべての $\mathrm{SiO}_{2}$ 添加の場合に促進効果が見られる ようになる。しかし，乙の場合にも $0.3 \%$ 位の微量の添 加が最も効果があることがわがた。

次に焼成試験片の粉末 X線回折を行ない，その組成銛 物の変化を検討するとともに，一部の組成䤨物について は金属 Si を内部標準としてその量的な変化を明らかに した. $\mathrm{MgO}$ の焼結に対する $\mathrm{SiO}_{2}$ 効果は, $\mathrm{SiO}_{2}$ が $\mathrm{MgO}$ に固溶するからだとする報告があるので，さらに $\mathrm{MgO}$ の格子定数值を算出してその変化を検討したが，その結 果からは，明らかに固溶するとする積極的な結論は得ら れなかった。しかし，焼成温度による $\mathrm{MgO}$ の格子定数 值の変化加ら, $\mathrm{SiO}_{2}$ の添加は, $\mathrm{Mg}(\mathrm{OH})_{2}$ の分解真後 の構造的に遅緩した $\mathrm{MgO}$ の宾定化を促進することが推 定された。

また $\mathrm{SiO}_{2}$ が共存する場合には $\mathrm{MgO}$ のリスタリッ

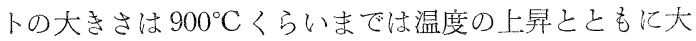
きくなるが，それ以上は恋化せず，特に $\mathrm{MgO}$ 単味の場 合に $1500^{\circ} \mathrm{C}$ 以上で起る急速なクリスタリットの成長を 押气る効果があるととがわかった。 


\section{(東京工業大学)}

3. $\mathbf{N i}^{2+}$ を置換固溶するチタン一錫-クロム, およびチ タンーアルミニウムークロム系単一スピネルの生成と発 色

\section{○大塚 淳・高橋祥介}

1) 目的多成分系単一スピネルの研究は余り行 なわれていないが, 新しい無機顔料の開発研究の一環と して $\mathrm{Ni}^{2+}$ を置換固溶する表記の多成分系単一スピネル について，その生成と発色とを検討するため行なったも のである。

2) 経 過 試料は三成分系の組成を示す三角形の 頂点がそれぞれ

A ( $\mathrm{NiO} \mathrm{ZnO} \mathrm{TiO}_{2}, \mathrm{NiO} \mathrm{ZnO} \mathrm{SnO}_{2}, \mathrm{NiO} \mathrm{Cr}_{2} \mathrm{O}_{3}$ )

B ( $\mathrm{NiO} \mathrm{MgO} \mathrm{TiO}_{2}, \mathrm{NiO} \mathrm{MgO} \mathrm{SnO}, \mathrm{NiO} \mathrm{Cr}_{2} \mathrm{O}_{3}$ )

C ( $\mathrm{NiO} Z \mathrm{ZnO} \mathrm{TiO}_{2}, \mathrm{NiO} \mathrm{Al}_{2} \mathrm{O}_{3}, \mathrm{NiO} \mathrm{Cr}_{2} \mathrm{O}_{3}$ )

D ( $\mathrm{NiO} \mathrm{MgO} \mathrm{TiO}_{2}, \mathrm{NiO} \mathrm{Al}_{2} \mathrm{O}_{3}, \mathrm{NiO} \mathrm{Cr}_{2} \mathrm{O}_{3}$ )

である. 4 つの 3 角形 A,B,C,D 亿ついて合計 150 種 の試料を調製した。試料の調製に際し， $\mathrm{NiO}$ には塩基 性炭酸ニッヶル, $\mathrm{ZnO}, \mathrm{MgO}, \mathrm{TiO}_{2}, \mathrm{SnO}_{2}, \mathrm{Cr}_{2} \mathrm{O}_{3}$ には 各酸化物の一級試楽を用い, 湿式で混合し, 炭化珪素発 熱体電気炉中で加熱し最高温度 $1350^{\circ} \mathrm{C}$ に 時間保持し た. 放冷後粉砕し, X線分析により単一スピネルの生成 を観察し，またその格子常数を求めた. また自記式分光 分析器により $\mathrm{Ni}^{2+}$ および $\mathrm{Cr}^{3+}$ の吸収の移動を検討し た。

\section{3) 結 論}

（1） Aでは全域で単一スピネルを得た。三角形内部 では, 多数の新しい $\mathrm{NiO}-\mathrm{ZnO}-\mathrm{TiO}_{2}-\mathrm{SnO}_{2}-\mathrm{Cr}_{2} \mathrm{O}_{3}$ 系 単一スピネルが生成した。との系では $\mathrm{NiOCr}_{2} \mathrm{O}_{3}$ にお いてのみ $\mathrm{Ni}^{2+}$ は完全に 4 配位 $\mathrm{Ni}^{2+}$ の吸収を示すが, $\mathrm{NiO} \cdot \mathrm{ZnO} \cdot \mathrm{TiO}_{2}, \mathrm{NiO} \cdot \mathrm{ZnO} \cdot \mathrm{SnO}_{2}$ の緑はいずれも6配位 $\mathrm{Ni}^{2+}$ のものである。 $\mathrm{Cr}^{3+}$ が入ると次第に 4 配位 $\mathrm{Ni}^{2+}$ の吸収が強くなる。

(2) $\mathrm{B}$ では $\mathrm{NiO} \cdot \mathrm{MgO} \cdot \mathrm{SnO}_{2}, \mathrm{NiO} \cdot \mathrm{MgO} \cdot \mathrm{TiO}_{2}$ の 組成の単一スピネルは $1350^{\circ} \mathrm{C}$ では得られなかった。単 一スピネルは $\mathrm{Cr}^{3+} \mathrm{Ti}^{4+}$ の多い組成で得られ，Aの場合 同様 $\mathrm{Cr}^{3+}$ が増すと4 配位 $\mathrm{Ni}^{2+}$ の吸収があらわれて, 緑から黒緑にかけての色調を得た。

（3） Cでは全域で単一スピネルが生成し, 三角形内 部で多数の新しい $\mathrm{NiO}-\mathrm{ZnO}-\mathrm{TiO}_{2}-\mathrm{Al}_{2} \mathrm{O}_{3}-\mathrm{Cr}_{2} \mathrm{O}_{3}$ 系単 一スピネルを得た。この系では $\mathrm{NiO} \cdot \mathrm{Al}_{2} \mathrm{O}_{3}$ で $\mathrm{Ni}^{2+}$ の 約 $25 \%$ が 4 配位の位置にあり青色を示し, 全域で青〜 青緑〜濃緑にかけての発色を得た。

（4） $\mathrm{D}$ では $\mathrm{NiO} \cdot \mathrm{MgO} \cdot \mathrm{TiO}_{2}$ は $\mathrm{B}$ の場合亡同様， 単一スピネルでなく, $\mathrm{Al}^{3+}, \mathrm{Cr}^{3+}$ の多い組成で $\mathrm{NiO}-$ $\mathrm{MgO}-\mathrm{TiO}_{2}-\mathrm{Al}_{2} \mathrm{O}_{3}-\mathrm{Cr}_{2} \mathrm{O}_{3}$ 系の単一スピネルが得られ た・色調の組成による変化は（3）のC と大体同じであ る.

(横浜国立大学工学部)
4. フォルステライトーテフロイト系固溶磁器（マンガ ンフォルステライト磁器) の熱膨脹と電気的特性 ○深瀬雅彦・斎藤光司

1) 目的 フォルステライト，すなわちオルト珪 酸マグネシウムはフォルステライト磁器の主成分とし て，今日広く低損失絶縁材料として用いられている。 Glasser, Dowen, Sarver などの研究によると, オルト 珪酸マグネシウムは $\mathrm{Mn}, \mathrm{Fe}, \mathrm{Ca}$ および $\mathrm{Zn}$ などと固 溶するととが知られている。とくに Glasser は最近再び $\mathrm{MgO}-\mathrm{MnO}-\mathrm{SiO}_{2}$ 系の研究で, $\mathrm{Mg}_{2} \mathrm{SiO}_{4}$ と $\mathrm{Mn}_{2} \mathrm{SiO}_{4}$ と が完全固溶するととを認め，相平衡関係や屈折率などに ついて発表している。しかし，その他の性質については 全く述べていない。演者らは $\mathrm{Mg}_{2} \mathrm{SiO}_{4}-\mathrm{Mn}_{2} \mathrm{SiO}_{4}$ 系固溶 磁器, すなわち $\mathrm{Mg}_{2} \mathrm{SiO}_{4}$ の $\mathrm{Mg}$ を $\mathrm{Mn}$ で置換固溶さ せた磁器の熱膨脤, 電気的特性などを調べ, 電気材料之 しての可否を検討した。

2) 経 過 原料は主原料として珪石, $\mathrm{Mg}(\mathrm{OH})_{2}$, $\mathrm{MnCO}_{3}$ を用い, 融剤としてカオリン, $\mathrm{Nd}_{2} \mathrm{O}_{3}$ をそれぞ れ $3 \%$ (重量) 用いた。 $4 \mathrm{Gc}$ 帯での誘電特性の測定は, 摂動法を用い，その温度特性は室温から $400^{\circ} \mathrm{C}$ まで行な った。

実験結果は次のようである。Mn の置換量の増加と共 に焼成温度は下り，素地の比重は大きくなり，3.1 から 4.05 になった。熱膨脤係数も Mn の増加と共に直線的 に減少した。 $4 \mathrm{Gc} / \mathrm{s}$ における誘電率 $\varepsilon^{\prime}$ は， Mn の増加 と共に大きくなり，6.2から8.40変化がみられ， $\tan \delta$ は極めて小さいが, Mn の增加と共に増加の傾向がみら れ，0.2 3.0 ( $\left.\times 10^{-4}\right)$ の間にあった. $\varepsilon^{\prime}, \tan \delta$ の温度 特性はMnの増加と共に，また高温になるに従って大き くなる傾向がみられた. $\varepsilon^{\prime}, \tan \delta$ の周波数特性, たとえ ば $\left(\mathrm{Mg}_{0.5}, \mathrm{Mn}_{0.5}\right)_{2} \mathrm{O} \cdot \mathrm{SiO}_{2},\left(\mathrm{Mg}_{0.3}, \mathrm{Mg}_{0.7}\right){ }_{2} \mathrm{O} \cdot \mathrm{SiO}_{2}$ それぞれ主成分とする磁器については，低周波側で大き くなる。乙の傾向は Mn 量の大きいほど大きい。体積固 有抵抗 $\sigma$ は $\mathrm{Mn}$ 量の増加と共に減少し, その温度特性 は，たとえば $200^{\circ} \mathrm{C}$ で，置換 $\mathrm{Mn}$ が $\mathrm{Mn}_{0.2}, \mathrm{Mn}_{0.3}$ ， $\mathrm{Mn}_{0.8}$ の場合， $\sigma$ はそれぞれ $1 \times 10^{13}, 3 \times 10^{12}, 3 \times 10^{8}$ ( $\Omega-\mathrm{cm})$ であった。

3) 結 果 $(\mathrm{Mg}, \mathrm{Mn})_{2} \mathrm{O} \cdot \mathrm{SiO}_{2}$ 系を主成分とする 磁器において, Mn 量の増加と共に熱膨脹は直線的に減 少し, $\mathrm{Mn}_{0.7} \sim \mathrm{Mn}_{0.7}$ の場合, $\mathrm{Ti}$ 金属と熱膨脹が極めて 近似し， $\mathrm{Ti}$ との封着が可能なととを示した。 Mo 法に よるメタライズは，素地中に Mn が含まれるため，極め て効果的であることが推定される、マイクロ波における 誘電特性は極めて低損失で, その温度特性, また体積固 有抵抗も可成すぐれているととがわかった。したがって 高周波，とくにマイクロ波，乏リ波帯における低損失杜 料として実用出来ることを示している.

（電気通信研究所） 


\section{5. 覀鉛失透嬏の組織の電子顕微鏡観察}

\section{○高島広夫・加藤悦三}

1) 目的亚鉛の含有量が著しく多く独得の失透 釉, 結晶釉を作る釉を亜鉛釉と呼ぶ。乙の種の釉（系） では 2 種類の失透釉が現われる。一つは $\mathrm{Al}_{2} \mathrm{O}_{3}$ の多い組 成の釉でできるもので，従来からブリストル型失透釉と して知られているものであり，他は $\mathrm{Al}_{2} \mathrm{O}_{3}$ の少ない組 成領域に現わ机る。前者の失透釉では分散相はスピネル であるこ之がX線分析により明らかになったが，後者の 釉ではX線分析によっては結晶相が認められなかった。 それで電子顕微鏡によって，その乳濁釉の組織を観察す るととにした。

2）経 過 代表的な亜鉛釉（系）として, 次のも のを選ぶ.

$$
\left.\begin{array}{l}
0.20 \mathrm{KNaO} \\
0.60 \mathrm{ZnO} \\
0.20 \mathrm{CaO}
\end{array}\right\} \quad 0.15 \sim 0.65 \mathrm{Al}_{2} \mathrm{O}_{3} \cdot 1.5 \sim 5.0 \mathrm{SiO}_{2}
$$

この釉系には結晶釉, 透明釉，および上記の 2 種類の 失透釉が現われる。それらの失透釉の分散相の $\mathrm{X}$ 線分析 および電子顕微鏡観察を行なう. 電子顕微鏡観察は, 失 透釉の表面を $4 \% \mathrm{HF}$ 溶液でエッチングしレプリカ法で 行なった. 失透釉の電子顕微鏡的組織を透明釉, 元来失 透するものを急冷して透明にした釉などと比較検討し た。また, 結晶による失透釉については化学的処理によ りその結晶を判別するととを試みた。

3) 結 論 $\mathrm{Al}_{2} \mathrm{O}_{3}$ の含有量の多い組成でできる失 透釉ではX線分析により結晶相はスピネルであることを 知った. そして $\mathrm{HF}+\mathrm{H}_{2} \mathrm{SO}_{4}$ 処理により婇のスピネル相 を分離し, 化学分析によって, このスピネルは $\mathrm{ZnO}$. $\mathrm{Al}_{2} \mathrm{O}_{3}$ であることを確認した。なお，電子顕微鏡による 観察では, スピネルの結晶の大きさは 1 3 $\mu$ であるこ とがわかった。

$\mathrm{Al}_{2} \mathrm{O}_{3}$ の含有量の少ない失透釉では, X線回折により 結晶相は認められなかった。従ってての失透は分相によ ると考元られるが，その電子顕微鏡写真によれば，非常 にてまかい大きさのそろった無定形物質の分散が認めら れた. 電子顕微鏡で $0.2 \sim 0.3 \mu$ の無数のこまかい円形 の穴が観察され，この穴は酸に窝蝕されやすい分相分散 相に相当すると考学られる。それを確認する意味で透明 橎および失透嬏を急冷して得た透明釉について同様な観 察を行ない，透明舳では窝蝕による穴が非常にこまか く $0.05 \mu$ 以下であるてと，また失透のでく弱い勫では $0.1 \mu$ 前後であることを認めた. てのように失透と透 明，または失透の強弱が電子顕微鏡で観察される窝蝕組 織とはっきりした関係が認められたので，てれが失透の 原因となる分相分散組織に相当するものであると考えて よいだろう。

(名古屋工業技術試験所)

\section{6. ホットプレスによるフェライトの焼結過程 とその}

\section{電気的磁気的性質}

岡畸 清・○柏原 茂・五十嵐秀二

1) 目的演者らは, 今まで各種強誘電体磁器の ホットプレスによる焼結過程について報告してきた。そ の結果，高温で 100〜1 kg/ $/ \mathrm{cm}^{2}$ の圧力を加えるてとによ り，充分緻密に焼結した密度を有する磁器が普通焼成に くらへてて $100 \sim 400^{\circ} \mathrm{C}$ も低温で得られた。また, $\mathrm{BaTiO}_{3}$ などの強誘電性磁器では, ホットプレスによりキュリー 点附近で誘電率のピークがほとんど失われた特性の試料 を得た。この原因は，ホットプレスによる加熱処理温度 の低下，粒成長の抑制による効果以外に，ホットプレス 時の残留歪が大きな寄与をしているようである。今回 は， $\mathrm{Cu}-\mathrm{Zn}$ フェライトおよび Ni-Zn フェライトについ てホットプレス時の焼結過程を調べ，かつその電気的磁 気的性質を明らかにするための実験を行なった。

2）経過実験化用いた装置は環状炉と高圧成形 機より成る. $900^{\circ} \mathrm{C}$ 以下の温度における加圧実験には, ステンレスの金型を，それ以上の温度では肉厚 $15 \mathrm{~mm}$ のアルミナ磁器の型を用いた。しの実験に用いた試料 は, $\mathrm{CZ}-4\left(0.4 \mathrm{CuO}+0.6 \mathrm{ZnO}+\mathrm{Fe}_{2} \mathrm{O}_{3}\right)$ と $\mathrm{NZ}-3(0.3$ $\left.\mathrm{NiO}+0.7 \mathrm{ZnO}+\mathrm{Fe}_{2} \mathrm{O}_{3}\right)$ の 2 種類である。ホットプレス 時の最高温度 $\left(T_{m}{ }^{\circ} \mathrm{C}\right)$, ホットプレスの圧力 $\left(P_{h} \mathrm{~kg} / \mathrm{cm}^{2}\right)$, および $T_{m}$ で $P_{h}$ を加えた時間 $\left(t_{p} \min \right)$ をかえながら 燒結特性を調べた。また，ホットプレスにあたり，最高 温度 $T_{m}$ 亿達してから圧力を加える方法 (SP 法), 常 温から $T_{m}$ に達するまで一定の圧力 $P_{h}$ を加党る方法 (DP 法)，および，常温から $T_{m}$ に達するまで，压力の 方も逐次上昇させ, 最後に $P_{h}$ が加わる方法 (GP 法) などを試みた。ホットプレスした円板試料の両面に In$\mathrm{Hg}$ を塗布して固有抵抗を測定した．また，円板より超 音波加工により，環状試料を抜出し，乙れに巻線を施し B-H 曲線, 初透磁率 $\left(\mu_{0}\right)$, 損失などを測定比較した。 さらに, 直径 $1 \mathrm{~mm}$ 程度の球状試料を作成して, マイク 口波 $(7000 \mathrm{Mc})$ 帯における吸収特性を測定した。

3) 結 論 CZ-4 は, 普通焼成に上ると $950^{\circ}$ $1050^{\circ} \mathrm{C}$ で燒結するが $T_{m}=850^{\circ} \mathrm{C}, P_{h}=500 \mathrm{~kg} / \mathrm{cm}^{2}, t_{p}$ $=30$ 分間程度のホットプレスにより普通焼成上同程度 の密度になる、しかし, 压力の加え方により, 焼結特性 は著しく異なり，GP 法によるときには焼結は全く進行 しない、最も燒結がすすむ压力の加え方は SP 法であっ た、ホットプレスした試料は, 普通焼成の同等程度の密 度の試料と比較して, 固有抵抗值はやや低く， $\mu_{0}$ はか なり低い,また， B-H 曲線から求めた抗磁力は相当大 きな值となった。

NZ-3 の場合でも, ホットプレスによれば普通焼成の 場合より $200^{\circ} \mathrm{C}$ 程度低い温度で焼結させることができ た. $T_{m}=1200^{\circ} \mathrm{C}, P_{h}=100 \mathrm{~kg} / \mathrm{cm}^{2}, t_{p}=30$ 分間のホッ トプレスを行なった試料の $\mu_{0}$ は温度とともに急激に低 
下し，普通焼成のものとかなり異なった特性を示した。

(防衛大学校電気工学教室)

7. 酸化還元多段階焼成法による $\mathrm{MnO} \cdot \mathrm{ZnO} \cdot 2 \mathrm{Fe}_{2} \mathrm{O}_{3}$ フェライトの電磁気的特性について（各種フェライトの 基礎的並びに製造に関する研究, 第 15 報)

磯松領造・○北川達人

1）目的酸化還元多段階焼成法による $\mathrm{MnO}$. $\mathrm{ZnO} \cdot 2 \mathrm{Fe}_{2} \mathrm{O}_{3}$ フェライトの製造は，低火度高速度焼成 法として好ましいてとが反応速度論的研究汃らき認めら れた。今回はこのようにして得られたフェライトの $\mu, Q$ 特性をしらべ，市販フェライトおよび酸化焼成法で得た フェライトの $\mu, \mathrm{Q}$ 特性と比較し, 焼成法の相違, 特に 䨌冉気の影響を比較検討せんとした。

2) 経 過 酸化還元多段階焼成法に上り $\mathrm{MnO}$ $\mathrm{ZnO} \cdot 2 \mathrm{Fe}_{2} \mathrm{O}_{3}$ フェライトを得るためには次の製造工程 が取上げられた。試料 No. 1 の製法は次の通り。

(a) まず $\mathrm{Mn}^{++}$と $\mathrm{Fe}^{+++}$を 1:2 モル比で含む溶 液より $\mathrm{NH}_{4} \mathrm{OH}$ を用いて $\mathrm{Mn}(\mathrm{OH})_{2}$ 己 $\mathrm{Fe}(\mathrm{OH})_{3}$ を共 沈させる。

（b）共沈物を一酸化炭素還元性䨌囲気中で $1000^{\circ} \mathrm{C}$, 7 時間焼成し, $\mathrm{MnO} \cdot \mathrm{Fe}_{2} \mathrm{O}_{3}$ フェライトを得る。焼成物 を粉砕して焼粉之する。

(c) 別に $\mathrm{Zn}\left(\mathrm{NO}_{3}\right)_{2}$ 己 $\mathrm{Fe}\left(\mathrm{NO}_{3}\right)_{3}$ 並びに $\mathrm{NH}_{4} \mathrm{NO}_{3}$ 存 $1: 2: 1$ モル比に混合し, アルミナ坩堝中で $800^{\circ} \mathrm{C}$, 3 時間強酸化性䨌围気中で焼成し, $\mathrm{ZnO} \cdot \mathrm{Fe}_{2} \mathrm{O}_{3}$ フェラ イトの焼粉を得る。

(d) てのようにして (b) で得た $\mathrm{MnO} \cdot \mathrm{Fe}_{2} \mathrm{O}_{3}$ フェ ライトの焼粉と (c) で得た $\mathrm{ZnO} \cdot \mathrm{Fe}_{2} \mathrm{O}_{3}$ フェライトの 焼粉を等モル比で混合し, 直径 $40 \mathrm{~mm}$, 厚さ $10 \mathrm{~mm}$ の リング状に成形して, 弱還元性穹围気中で 3 時間, 引続 き中性雾国気中で 3 時間, それぞれ $1150^{\circ} \mathrm{C}$ で焼成し $\mathrm{MnO} \cdot \mathrm{ZnO} \cdot 2 \mathrm{Fe}_{2} \mathrm{O}_{3}$ フェライトを得た。

また，一方試料 No. 2 の製法は次の通りである.

(e) $\mathrm{MnCO}_{3}$ と Goethite の等モル比混合物を (b) と同に方法で焼成する.

(f) 別に $\mathrm{ZnO}$ 之 Goethite の等モル比混合物老 (c) つ条件で焼成し， $\mathrm{ZnO} \cdot \mathrm{Fe}_{2} \mathrm{O}_{3}$ フェライトを得，粉研し て焼粉之する。

( g) (e) で得た $\mathrm{MnO}$ 。 $\mathrm{Fe}_{2} \mathrm{O}_{3}$ 焼粉之（f）で得た $\mathrm{ZnO} \mathrm{Fe}_{2} \mathrm{O}_{3}$ 焼粉を等モル比で混合, 成形し，(d) の方 法で本燒成を行なう。

このようにして得た 2 種の試料の $\mu, Q$ 特性を測定し， 酸化焼成法による試料押よび市販品と比較した。

3) 結 諭 $\mu, Q$ 特性測定の結果, 本研究で得た $\mathrm{MnO} \cdot \mathrm{ZnO} \cdot 2 \mathrm{Fe}_{2} \mathrm{O}_{3}$ フェライトは, $\mathrm{Q}$ 特性に関しては他 と大差はない。しかしル特性纹酸化法による試料や市 散品に比心周波数の高い方が良好で, $2 \mathrm{Mc}$ 付近に弱い ピークを有するものも得られた。特に湿式法で得たフェ
ライトはこの特徴が著しく, 従来のフェライトに比べ周 波数の高い領域まで使用可能なととを示しており, それ だけ使用帯域が広がったととが確認された。

(同志社大学工学部)

\section{〔特別講演〕（原料部会）}

窵業原料選鉱の現状々将来の展望 ( 1 時間)

$$
\text { .三菱金属鉱業 (株) 採鈗部 瀬戸英太郎 }
$$

\section{8. 高鉛ガラスの高温にむける揮発について}

○寺井良平・吉田伸雄

1）目的鉛ガラスは熔融中にはなはだしく揮発 する。それは炉材に実害を与え，同時にガラス中にも不 均質部を作る。乙れらは脈理の有力な原因となるであろ う，そこで高鉛含有ガラスの熔融中における揮発の過程 を, 各種ガスを流入した炉内霖团気のもとで調心゙, 揮発 現象を支配する要因を検討しようとした。

2) 経過光学ガラス SFS 1 亿近い組成の二, 三の高鉛ガラス（鈶メ夕球酸塭予よびてれに $\mathrm{K}_{2} \mathrm{O}$ を 5 , $10 \mathrm{~mol} \%$ 添加）を，乾燥酸素，乾燥窒素，10\% 水蒸気 含有空素, $0.2 \sim 0.4 \%$ 业硫酸方ス混入 $10 \%$ 水蒸気含 有窒素などの各種ガスの需囲気中で, 各種温度に保持し ながら, その揮発過程を熱天科により観測した。 また揮 発前後の試料ガラスの化学分析, 揮発凝結物のX線回折 と化学分析によって, 揮発物の実体についても検討し た。同時にてのガラスの粘性係数も測定し, 揮発過程々 の関連性を調べた。鈶を含まない二，三のガラスの揮発 過程とも比較した。

3) 結 論高鉛ガラスの揮発量の時間的変化は, 初期段階を除いて，時間の平方根汶して，ほ汶1本の 直線として表わさ札る。乙の直線の勾配から求わた見か けの活性化エネルギーは, 鉛メ夕珪酸塩ガラスのばあ い, 約 $76 \mathrm{kcal} / \mathrm{mole}$ となり，てれに $\mathrm{K}_{2} \mathrm{O}$ の添加され た 2 種のガラスではこれぞれ $60,50 \mathrm{kcal} / \mathrm{mole}$ となっ た. $\mathrm{K}_{2} \mathrm{O}$ が添加されると, それ対応して揮発速度も 増大するが，乙れら统， $\mathrm{K}_{2} \mathrm{O}$ 添加によるガラスの粘性 の低下, 粘性流動の活性化エネルギーの減少と相対応し ている。

初期段階は相当長時間続き(低温側約 6 時間, 高温側 約 2 時間) その初期速度から求めた活性化エネルギーは 55〜43 kcal $/ \mathrm{mole}$ であった。

てれらの過程は㚸内雾罒気中の酸素の有無, 水蒸気の 有無とは余り関係がなく, 水蒸気の影響を受けるソーダ メ夕珪酸塩ガラスと封照的である。ただ西硫酸ガスを少 量混入した場合のみ, 撜発過程の後半でその速度が低下 したが, ての傾向は高温活ど, また低粘性のガラス程顕 著であった。

揮発によってガラスから奪わ和る成分は主としてPbO であり， $\mathrm{SiO}_{2}, \mathrm{~K}_{2} \mathrm{O}$ は活とんど逃散していないととがわ かった。てのことは凝結物の分析によっても確認した 
が，X線回折は $\mathrm{PbO}, \mathrm{Pb}_{3} \mathrm{O}_{4} \cdots \cdots$ の存在を示した。亜硫 酸ガスを流した場合は大半が $\mathrm{PbSO}_{4}$ として凝結してい た。

これらの事実から，ての種のガラスの揮発現象は，ガ ラス成分 $\mathrm{PbO}$ の逃散であり, さ总に求めた見かけの活 性化エネルギーが，初期にあってはP P O 蒸発熱に近 く, 後半にあっては酸素イオンの搪散に要するエネルギ 一飞近いととから, 熔融趇面からのP PbO の単純な揮発 に擬せられる初期段階と，熔融ガラス中に生じた濃度勾 配中を $\mathrm{Pb}, \mathrm{O}$ 方拡散する過程とからなると想像される。 (大阪工業技術試験所)

\section{9.インジウムを用いたガラス接着体の応力}

\section{岸井＼cjkstart貫}

1) 目的電子管では，膨脹係数差のあるガラス の接着，低温での気密封着形成などにインジウムを利用 する、インジウムは常温でも可塑性があるので，封着体 の応力特性は，他種の封着体と異なると予想される。乙 の点を，実測で調べようとした。

2) 経 過 $10 \times 50 \times 3 \mathrm{~mm}$ の各種ガラス片をイン ジウムで接着して，バイメタル形の接着体とし，その中 の応力分布と, 温度変化に之もなう応力の変化之を光弾 性で測った。

3）結 論主応力線はほとんぞ接着面に平行であ る。応力值は端部ではゼロに近く，中央部で極大になる ような分布をする。接着後の冷却速度が応力に及ぼす影 響は比較的小さい，接着体に外部から曲げ応力を加える 之, 応力分布が変る場合がある. $90^{\circ} \mathrm{C}$ 附近の比較的高 い温度では, 定温保持によって応力が緩和する。温度サ イクルを与えると，顕著な履歴現象が誌められる。ガラ ス片の一面にインジウムを盛り上げただけでは，応力は 非常に小さい。

これらの特性は，次の上うな仮定を置く之説明でき る. i）インジウムの, 自由表面附近での応力は実際上 無視できる。したがって，その附近の接着体内の，てれ に直角な方向の応力はゼロである。ii）インジウムが単 位接着面積当りに支党うる，ガラス間の膨脤差あるいは 接着体の曲げ応力には限界值がある。iii）この限界以上 の膨脹差や応力が生じようとすると,インジウムは塑性 流動をして応力增加を防ぐ，iv）この限界值は高温にな るにつれて減少し，インジウムの融点附近で急減する。 v）接着体の定温度保持により，乙の限界を低下させう る。その程度は, 常温では僅かげが, インジウムの融点 附近では顕著である。vi）膨脹差または曲げ応力がての 限界内にあれば，インジウム層の変形は弾性的であり， 接着体の変形や応力も弾性的である。

(東京芝浦電気 (株) 中央研究所)

\section{0. $\mathrm{Na}_{2} \mathrm{O}-\mathrm{B}_{2} \mathrm{O}_{3}-\mathrm{SiO}_{2}$ 系ガラスの熔融時の揮発} 新保優
1) 目的硼理酸塩系ガラスでは熔融時の成分の 揮発が特に著しく，製品の欠点の原团々なる場合が多 い、したがって，ての種のガラスの揮発に関する報告も 少なくないが，揮発現象はガラス組成，炉雾用気，測定 装置の大きさなど測定の条件に大きく左右されるため， これらに関する基整的定量的な結果を得ることはガラス 製造上のみならず，揮発の機作を知る上亿有意義である 之思われる。

ここではまず簡単のために $\mathrm{Na}_{2} \mathrm{O}-\mathrm{B}_{2} \mathrm{O}_{3}-\mathrm{SiO}_{2}$ 三成分 系をとり，製造上重要な組成範囲について組成之揮発量 の関係を求めて考察する.

2) 経 過 $\mathrm{Na}_{2} \mathrm{O}-\mathrm{B}_{2} \mathrm{O}_{3}-\mathrm{SiO}_{2}$ 系ガラスのうち $\mathrm{SiO}_{2}$ 60 85 重量\%の範囲のうち各成分を $5 \%$ 間隔でと り，30 種のガラスを作って試料とした。熔融には 300 cc の白金坩堝を用い，組成によって $1300^{\circ} \sim 1600^{\circ} \mathrm{C} の$ 温度で低温では電気弱，高温ではガス炉で 4 時間加熱 し，鉄板上で急冷して試料とした，得られたガラスは化 学分析を行ない,バッチ組成からの变化を補正した。不純 物はすべてのガラスについて $\mathrm{Al}_{2} \mathrm{O}_{3} \quad 0.1 \%, \mathrm{Fe}_{2} \mathrm{O}_{3} 0.02$ $\%, \mathrm{~K}_{2} \mathrm{O}<0.01 \%$ (重量) 内外である.

揮発量測定にはダブルスパイラル形炭化珪素発熱体を 用いた熱天秤を使用した。すなわち7〜20メッシュに粉 砕したガラス $5 \mathrm{~g}$ を直径 $18 \mathrm{~mm}$, 高さ $18 \mathrm{~mm}$ の白金容 器にとり, 炉上の化学天秤から白金線でつるし， 1 時間 ごとに 6 時間重量変化を測定した。測定温度は $1410^{\circ} \mathrm{C}$ である。測定中は乾燥空気を $30 \mathrm{cc} / \mathrm{min}$ の速度で炉下部 から送った，炉内管は $35 \mathrm{~mm}$ の径である，炉の温度分 布はほぼ一定であが，2〜3 の試料について着色ガラス を熔融試料の表面にのせて熔融中のガラスの対流を調べ た。

3) 結 論 $\mathrm{Na}_{2} \mathrm{O}-\mathrm{SiO}_{2}$ 二成分系を除き，いずれ の試料も時間之共に揮発量は減少する。 6 時間後の等揮 発総量曲線を 図-1 に示す. 揮発量は $\mathrm{SiO}_{2}$ 量の増大と

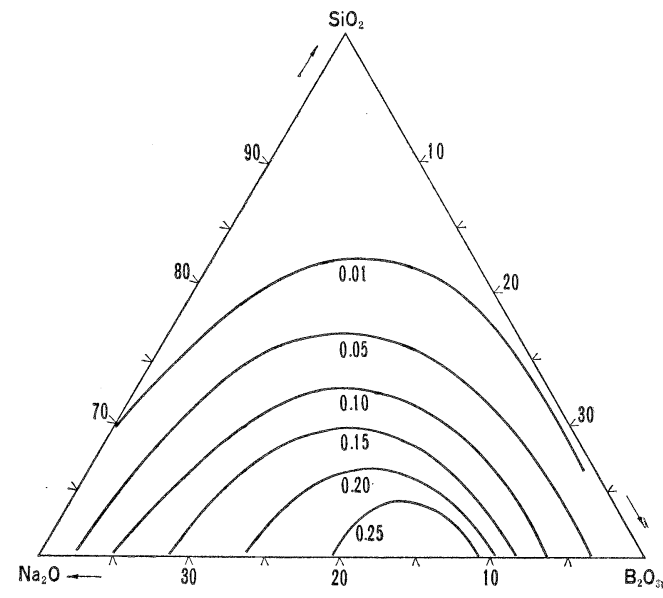

図-1 $\mathrm{Na}_{2} \mathrm{O}-\mathrm{B}_{2} \mathrm{O}_{3}-\mathrm{SiO}_{2}$ 系ガラスの等揮発量曲線 $1410^{\circ} \mathrm{C} 6$ 時間後 $\left(\mathrm{g} / \mathrm{cm}^{2}\right)$ 
共に減少し，等 $\mathrm{SiO}_{2}$ 量では $\mathrm{SiO}_{2}$ 量の多い組成では $\mathrm{Na}_{2} \mathrm{O}$ 対 $\mathrm{B}_{2} \mathrm{O}_{3}$ 量の比が $1: 1$ のと最大を示すが $\mathrm{SiO}_{2}$ 量の減少と共に $\mathrm{B}_{2} \mathrm{O}_{3}$ の多い方にピークが移動する。 $\mathrm{B}_{2} \mathrm{O}_{3}$ 量の多い分相域では一定 $\mathrm{Na}_{2} \mathrm{O}$ の場合，揮発量は $\mathrm{SiO}_{2}$ によらずほぼ定であるが， $\mathrm{Na}_{2} \mathrm{O}$ の多い場合， $\mathrm{B}_{2} \mathrm{O}_{3}$ 一定々すると $\mathrm{SiO}_{2}$ 量增大と共に揮発量㥀線的 に減少する. $\mathrm{SiO}_{2} 75 \%$ 以上では測定中に多くの表面失 透層が生じ，一定時間以後揮発量は著しく減少する。 $\mathrm{Na}_{2} \mathrm{O}-\mathrm{SiO}_{2}$ 系では揮発量之時間之は直線関係省る。 また， $\mathrm{B}_{2} \mathrm{O}_{3}: \mathrm{Na}_{2} \mathrm{O}$ が 1:10組成付近ではガラス中に かなりの対流があるにもかかわらず時間の平方根と揮発 量とは直線関係となり，拡散律速の様子を呈する。

(東京芝浦電気 (株) 中央研究所)

\section{1. 窒化研絮の製造}

矢野友三郎・ ○松尾 正

1) 目的窒化硼素は黒鉛と類似の層状格子を老 っているととから, White graphite として知られてい る物質である。この物質は不活性雾囲気では $3000^{\circ} \mathrm{C}$ 附 近まで安定で, 電気絶縁性に優れ良好な耐蝕性之潤滑性 を示し，七ラミックのなかで唯一の機珹加工の出来る無 機材料で，高压相の等軸結晶はダイヤモンドより硬いと いわ机ており研究重要度は高い。䇪化硼素合成の歴史は 古く，既に1842 年に合成されてその後多くの检討がさ れているが，商用化されたのは最近のことである。本研 究は, ボロンの研究でボロン熔融坩堝用の唯一の材料で ある窒化硼素に注目し，その特徴ある性質を有する窒化 嗍素の合成・成形・物性測定およびその関連技術につい て検討したものである.

2) 経 過本研究では, 硼砂を原料とし尿素を窒 素源とする䇪化硼素の合成に*)成功し，その製造条件並 びにホットプレスによる成形方法を確立した，硼砂と過 剰の尿素の混合物を反応炉に入れて，アンモニ気流中
で $900^{\circ} \mathrm{C}, 2$ 時間処理し, 䇪化後, 副生成物を除却し 白色の結晶性窒化硼素を得た。窒化硼素の純度, 収率な ぞは硼砂と尿素の混合比，加熱速度で変わる。乙の粉末 を窒素気流中で $1800^{\circ} \mathrm{C}$ 燒成処理すると, 窒素含有量の 向上と絬晶生長が認められた。成形は内径 $80 \mathrm{pmm}$ の黑 鉛型に窒化硽素を充填し，ホットプレスにより各種雾团 気での圧力・温度・時間の依存性を検傠した。得られた 焼結体は加工性の良い高純度・自己結合の䇪化硼素であ った. 各試料についてX線・化学分析・物性試験を行な い比較検討した。

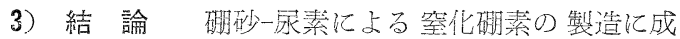

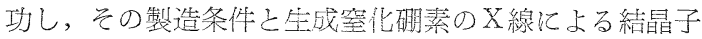
寸法を解明し，さらにホットプレスによる成形法につい ての諸条件を明ら汃にした。守なわら，種々の実踰結果 から碵砂。尿素の混合物老 $900^{\circ} \mathrm{C}$ にンモ二ヤ気流中 で加熱し, 反応終了後, 水洗・酸洗などの処理を行なっ た後, 乾燥して硯砂に対与る収率が $80 \%$ 以上, 窒素含 有量 $53.5 \%$ の粉末状咥化硼素在得た。乙の粉末は平均 粒径 0.03 ミクロンで, 結晶系は六方晶であり結晶子寸 法は $100 \AA$ 附近であ。た。乙京䇪素気流中で焼成す ると窒素含有量の向上之結晶生長が認められ， $1800^{\circ} \mathrm{C}$ では結晶子寸法 $300 \AA$, 窒素含有量 $56 \%$ 程度, 平均粒 径 0.5 ミクロンであった。次に成形条件は $1800^{\circ} \mathrm{C}$, 圧 力 $50 \mathrm{~kg} / \mathrm{cm}^{2}$ ，ホットプレス時間約 60 分では筒比重 1.70 〜 $1.80(\mathrm{~g} / \mathrm{cc})$ の密度のものが得られるととを確認し， 温度・圧力を上げるとと亿より，容易に少なくとも䇾比 重 2.00 以上に燒結可能であることがわかった。ての成 形体の物性測定結果は, 常温江方讨可比抵抗 $10^{12} \Omega-\mathrm{cm}$, 圧縮強度は $1000 \mathrm{~kg} / \mathrm{cm}^{2}$ 程度, 抗折力は $6 \mathrm{~kg} / \mathrm{mm}^{2}$ で あり，成形方向による異方性は認められなかった。

*) 特許出䫝公告 昭和 38-1610

（昭和電工株式会社） 